\title{
LEAD POISONING IN CHILDHOOD TREATED BY THE SUBCUTANEOUS ADMINISTRATION OF A CHELATING AGENT
}

\author{
BY \\ N. V. O'DONOHOE \\ From the Department of Child Health, University of Liverpool, and Alder Hey Children's Hospital, Liverpool
}

(RECEIVED FOR PUBLICATION APRIL 16, 1956)

The treatment of lead poisoning with the neutral calcium disodium salt of ethylene diamine tetraacetic acid (calcium disodium E.D.T.A.) was first described by Bessman, Ried and Rubin in 1952. Since then there have been many reports testifying to the value of this treatment, including those of Sidbury, Bynum and Fetz (1953), Karpinski, Rieders and Girsh (1953), Byers and Maloof (1954), Bessman, Rubin and Leikin (1954) and Giles, Moore and Still (1955). The preparation is marketed commercially as 'versenate' and belongs to a group of chemical agents known as chelating agents, this term being derived from the Greek word meaning a 'claw'. Chelating agents are capable of combining with certain metals to form firm complexes called chelates which are stable ring structures, water soluble and readily excreted. In them the metal is not ionized and therefore does not show its usual chemical or physiological activity. The strength, or stability, of the chelate varies with different metals, and one metal which forms a stable complex may displace a second metal whose complex is less stable. This fact is the basis of the therapeutic use of calcium disodium E.D.T.A. in lead poisoning. The affinity of lead for E.D.T.A. is greater than that of calcium and so, when calcium disodium E.D.T.A. is administered, lead will displace calcium from this complex and a lead disodium E.D.T.A. chelate will be formed. This particular chelate is very stable and is readily excreted in the urine; in this way the circulating lead is safely removed.

It was pointed out by Bessman et al. (1954) that, if calcium disodium E.D.T.A. acted at maximum efficiency, an excretion of about $260 \mathrm{mg}$. of lead should occur after the intravenous administration of $0.5 \mathrm{~g}$. of the drug. In fact, they observed that only $1.8 \mathrm{mg}$. of lead was excreted after this dose, representing an efficiency of only $0.7 \%$. The probable reason for this low efficiency is that lead is bound in the tissues to sulphahydryl groups and, although the affinity of lead for calcium disodium E.D.T.A. is greater than for the sulphahydryl groupings, they are much more numerous in the tissues. Bessman et al. found that increasing the dose of calcium disodium E.D.T.A. did not produce a corresponding increase in the excretion of lead and they suggested that this was probably due to the rapid excretion of the drug in the urine before it could be brought into equilibrium with the tissues. Because of this, they suggested that the drug should be given either by slow continuous intravenous infusion or by repeated intravenous administration at six-hourly intervals. A majority of the published cases of lead poisoning treated with calcium disodium E.D.T.A. have been given the drug by the intermittent intravenous administration of a dilute solution (not exceeding 3\% concentration). The drug has also been given orally (Bradley and Powell, 1954) but it is much less effective when administered by this route, and it may cause gastro-intestinal upsets.

Lead poisoning in childhood is almost entirely confined to children under 5 years of age. Tanis (1955) reported 33 cases; all of the children were aged less than 5 years and $70 \%$ of them were aged between 1 and 3 years. Mellins and Jenkins (1955) reported 21 cases with ages ranging from 10 months to 44 months. The usual cause of lead poisoning in childhood is the habit of chewing and eating paint from cribs, toys, furniture, woodwork or walls. The tendency to put things in the mouth, though normal in the first year of life, is considered abnormal if it is continued and it may then be referred to as a pica or perverted appetite. A history of pica was elicited in $94 \%$ of the cases reported by Tanis. Though lead paint is no longer used for interior decoration or for painting cots and toys, Gibb and MacMahon (1955) have pointed out that the amateur home decorator may believe that lead paints are the best paints and may apply them to internal surfaces and fittings. 
The fact that lead poisoning in childhood is most common in the toddler age group gives rise to certain technical problems when calcium disodium E.D.T.A. is used in treatment. As already mentioned, it is usually recommended that the drug should be given by intermittent intravenous administration of a dilute solution. By this route, the maximum dose per hour should not exceed $0.5 \mathrm{~g}$. per $30 \mathrm{lb}$., the maximum dose per day should not exceed $1 \mathrm{~g}$. per $30 \mathrm{lb}$. and the maximum dose per week should not exceed $5 \mathrm{~g}$. per $30 \mathrm{lb}$. Usually two courses of treatment are given, separated by a rest period of one week. Such a treatment schedule obviously involves repeated intravenous infusions and, in a plump toddler, it may be difficult to carry through the treatment without cutting down on veins.

So far, there have only been two references in the literature to the administration of calcium disodium E.D.T.A. by the subcutaneous route. Bessman et al. (1954) mention that the drug may be given in this way but do not discuss this method of administration in any detail. Kneller, Uhl and Brem (1955) described a case of lead poisoning in a child of 20 months; two courses of calcium disodium E.D.T.A. were given by subcutaneous clysis and the child made a complete recovery. No local reactions occurred.

Two further cases of lead poisoning in childhood, treated by the subcutaneous administration of calcium disodium E.D.T.A., are described here.

\section{Case Reports}

Case 1. This girl was aged $18 \frac{1}{2}$ months at the time of admission. She had not been well for about four weeks before admission with anorexia, frequent vomiting, constipation, intermittent abdominal pain and irritability as the main symptoms: convulsions had not occurred. During the three months before admission, the child had developed the habit of picking the paint off the inside of a window-sill and eating it. The father, who was a seaman, had painted the window-sill with a marine paint.

On examination, she looked pale and ill and it was evident that she had recently lost weight. Her weight was $21 \mathrm{lb}$. She was drowsy and extremely irritable. Apart frcm general muscular hypotonia, there were no other abnormal findings. There was no evidence of a lead line on the gums. Examination of the blood showed that the haemoglobin was $53^{\circ}{ }_{0}\left(7.9 \mathrm{~g} .{ }^{\circ}{ }_{0}\right)$; punctate basophilia was present. $X$-ray examination of the wrist revealed dense lines in the bones suggesting the deposition of a heavy metal. The C.S.F. was clear and contained protein $70 \mathrm{mg}$. ${ }^{\circ}{ }_{0}$, sugar $98 \mathrm{mg}$. ${ }^{\circ}$, and the test for globulin was positive: cells were less than 1 per c.mm. The urine contained a reducing substance, shown by chromatography to be glucose. Two-way chromatography revealed abnormal aminoacid ria: large amounts of glycine, alanine and serine, moderate amounts of taurine, threonine, histidine and $\beta$-amino-isobutyric acid, and small amounts of valine, leucine, tyrosine, cystine, lysine, aspartic acid and glutamic acid were present. Total serum protein was $5 \cdot 8 \mathrm{~g} .{ }^{\circ}$, with albumin $2 \cdot 62 \mathrm{~g} .{ }^{\circ}$, globulin $3 \cdot 18 \mathrm{~g}$. $\%$ and albumin: globulin ratio $0 \cdot 82: 1$.

Treatment with calcium disodium E.D.T.A. was started three days after admission. It was decided to give the drug by the subcutaneous route because it was felt that intravenous administration would involve cutting down on several veins. A $1^{\circ}$ o solution of the drug was made up in normal saline $(1 \mathrm{~g}$. in $100 \mathrm{ml}$.) and $25 \mathrm{ml}$. (0.25 g.) was given subcutaneously every six hours for five days (a total dose of 5 g.). At first the solution was given by drip infusion but subsequently it was found more convenient to give it by slow subcutaneous injection from a syringe, taking about 30 minutes to give $0 \cdot 25 \mathrm{~g}$. Hyaluronidase (1,500 international units) was given with each injection of calcium disodium E.D.T.A. A rest period of seven days was allowed after the first course and this was followed by the administration of a second course of the drug $(5$ g.) over a period of five days. Absorption of the drug was rapid from the sites of injection and the solution did not appear to cause any local pain. A small staphylococcal abscess developed at the site of one injection: this was incised and healed satisfactorily.

The child's condition began to improve 24 hours after starting treatment. She was brighter and less irritable: vomiting was less frequent and she began to accept food for the first time since admission. Over the next few days she improved rapidly; the improvement in her appetite was particularly striking and vomiting ceased completely. No stool was passed during the first seven days in hospital; subsequently her bowels became regular. Further general improvement took place during and following her second course of treatment. Examination of the blood after the second course of treatment showed that the haemoglobin was $58^{\circ}{ }_{o}\left(9.6 \mathrm{~g} .{ }^{\circ}{ }_{0}\right)$ : punctate basophilia was no longer present. The C.S.F. was again examined and contained protein $30 \mathrm{mg} .{ }^{\circ}$, and sugar $82 \mathrm{mg} .{ }^{\circ}$ : the test for globulin was negative and the cell count was 11 leucocytes per c.mm. $\left(65^{\circ}\right.$ o mononuclears). Chromatography of the urine showed that the amount of glucose was much less than before treatment: qualitatively there was still an abnormal aminoaciduria but the quantities of the amino-acids were much less.

The concentration of lead in the blood before treatment was started was $83 \mu \mathrm{g}$. ${ }^{\circ}{ }_{0}$ : after the completion of the second course of treatment the concentration was $50 \mathrm{\mu g}$. ${ }^{\circ}$. The urinary lead concentration was $280 \mu \mathrm{g}$. per litre before the start of treatment: on the second day of the first course it was $700 \mathrm{\mu g}$. per litre and, three days after the completion of the first course, it was $220 \mu \mathrm{g}$. per litre. (Normal values for lead in blood and urine are 10-30 $\mu \mathrm{g}$. ${ }^{\circ} \mathrm{o}$ and $30-80 \mu \mathrm{g}$. per litre respectively.)

During the convalescent period her appetite was voracious and she gained weight rapidly. Following a course of intramuscular iron ('imferon'), her haemoglobin rose to $80^{\circ}$. To date, she has been followed up 
for a period of six months, during which time her physical and developmental progress has been normal. There has been no recurrence of pica. The lead lines are still present on $x$-ray examination of the bones but they are gradually diminishing in intensity.

Case 2. This boy was aged 23 months at the time of admission. Anorexia, frequent vomiting, constipation, loss of weight and irritability had been noted for about four weeks before admission. Convulsions had not occurred. For about four months before admission, he had been picking paint off the outside of a window-sill and eating it.

On examination, he was pale, irritable and thin. His weight was $22 \mathrm{lb}$. Physical examination was otherwise negative: no lead line was present in the mouth. On examination of the blood his haemoglobin was found to be $57^{\circ} \mathrm{o}\left(8.5 \mathrm{~g} .{ }^{\circ}\right)$ : punctate basophilia was present. $X$-ray examination of the wrists revealed dense lines at the ends of the bones, suggesting the deposition of a heavy metal. The C.S.F. contained protein $80 \mathrm{mg}$. ${ }^{\circ}$, sugar $105 \mathrm{mg}$. ${ }^{\circ}$ and the test for globulin was positive; the cell count was normal. The urine contained a reducing substance, shown by chromatography to be glucose: small amounts of fructose and sucrose were also present. The test for coproporphyrin was positive. Two-way chromatography showed a greatly increased excretion of amino-acids, with large amounts of glycine, alanine, threonine and serine, moderate amounts of histidine, lysine and taurine, and small amounts of $\beta$-aminoisobutyric acid, cystine, valine, leucine, phenylalanine and tryptophane. Total serum protein was $7 \cdot 1 \mathrm{~g} .{ }^{\circ}$, with albumin $3.07 \mathrm{~g} .{ }^{\circ}$, globulin $4.03 \mathrm{~g} .{ }^{\circ}$ and albumin:globulin ratio $0 \cdot 75: 1$.

Treatment with calcium disodium E.D.T.A. was started two days after admission. The child's superficial veins were not prominent and it was therefore decided to give the drug subcutaneously as a $1^{\circ}$, solution in normal saline, $25 \mathrm{ml}$. $(0 \cdot 25 \mathrm{~g}$.) being given by slow subcutaneous injection every six hours for five days (a total dose of 5 g.). Each injection took about 30 minutes and hyaluronidase (1,500 international units) was given with each dose. A rest period of seven days was allowed after the first course and this was followed by the administration of a second course of $5 \mathrm{~g}$., again over a period of five days. No local complications occurred.

The immediate clinical response was not as striking as in Case 1, although the boy's appetite gradually improved and his bowels became regular during the week following the start of treatment. After the second course of the drug improvement was more marked; his disposition was happier and his appetite was normal. His haemoglobin after treatment was $62^{\circ}{ }_{0}\left(9 \cdot 2 \mathrm{~g} .{ }^{\circ}{ }_{0}\right)$ : punctate basophilia was absent. The C.S.F. contained protein $35 \mathrm{mg}$. ${ }^{\circ}$, sugar $62 \mathrm{mg}$. ${ }^{\circ}$ and the test for globulin was negative; the cell count was normal. The reducing substance was no longer found on chromatography and the abnormal aminoaciduria was quantitatively and qualitatively much less than on admission.

The concentration of lead in the blood before treatment was $108 \mu \mathrm{g}$. \%. Following the first course of treatment it was $200 \mu \mathrm{g}$. \% but it had fallen to $87 \mu \mathrm{g} .{ }^{\circ}$ five days later and before the start of the second course. Following the second course of treatment, it had fallen to $30 \mu \mathrm{g} . \%$. The urinary lead concentration was $160 \mu g$. per litre before the start of treatment; a figure of $344 \mu \mathrm{g}$. per litre was obtained after the first course and a figure of $206 \mu \mathrm{g}$. per litre after the second course.

The child improved steadily after discharge from hospital. His disposition was happy, his appetite was excellent and his bowels were regular. Pica did not recur. Iron therapy was not prescribed but, despite this, his haemoglobin was $83 \%$ o $\left(12 \cdot 3 \mathrm{~g} .{ }^{\circ} \%\right)$ seven weeks after the date of admission to hospital. So far, he has been followed up as an out-patient for six months, during which time his developmental progress has been normal. The lead lines are still present in the metaphyses of the bones but they are gradually diminishing in intensity.

\section{Summary}

The theoretical basis of the use of calcium disodium E.D.T.A. in the treatment of lead poisoning is discussed.

The age incidence and the causes of lead poisoning in childhood are mentioned.

The difficulties associated with the administration of calcium disodium E.D.T.A. are described.

Two cases of lead poisoning in childhood, successfully treated by the subcutaneous administration of calcium disodium E.D.T.A., are described.

I should like to thank Professor N. B. Capon for his advice and criticism, Drs. F. P. Hudson and S. E. Keidan for permission to publish details of cases admitted under their care and Mr. J. T. Ireland for the biochemical investigations.

Bessman, S. P., Ried, H. and Rubin, M. (1952). Med. Ann. Distr. Columbia, 21, 312 .

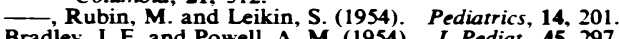

Byers, R. K. and Maloof, C. (1954). Amer. J. Dis. Child., 87, 559.

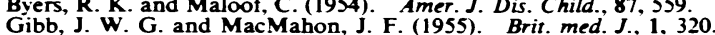

Giles, H. McC., Moore, C. J. and Still, B. M. (1955). Lancet, 1, 183.

Karpinski, F. E., Rieders, F. and Girsh, L. S. (1953). J. Pediat. 42. 687 .

Kneller, L. A., Uhl, H. S. M. and Brem, J. (1955). New Engl. J. Med., 252. 338.

Mellins, R. B. and Jenkins, C. D. (1955). J. Amer. med. Ass., 158. 15.

Sidbury. J. B., Bynum, J. C. and Fetz, L. L. (1953). Proc. Soc. exp. Biol. $(\hat{N} . Y), 82,$.

Tanis, A. L. (1955). Amer. J. Dis. Child., 89, 325. 